\title{
Political Initiatives and Peacekeeping: Assessing Multiple UN Conflict
}

\section{Resolution Tools}

Han Dorussen, University of Essex

Govinda Clayton, ETH-Zurich

27 July 2018 (Revised 16 September 2018)

\section{Corresponding author:}

Han Dorussen

Department of Government, University of Essex

hdorus@essex.ac.uk

Submitted to Peace Economics, Peace Science and Public Policy

Acknowledgements: previously presented at the 2018 Jan Tinbergen Conference of the Network of European Peace Scientists, University of Verona, June 2018. Research sponsored by the Folke Bernadotte Academy (dnr. 16-00444). 


\section{Introduction}

The effectiveness of United Nations (UN) peacekeeping has become a topic of extensive debate. Analyzing quantitative data on peacekeeper deployment, violent incidents, battlefield and civilian casualties, a number of studies have found that peacekeeping operations (PKOs) 'work’ by shortening conflict episodes (Ruggeri, Dorussen and Gizelis 2017), extending periods of political stability following conflict (Doyle and Sambanis 2000; Fortna 2008), and reducing casualties (Hultman, Kathman and Shannon 2013; 2014). Yet detailed case studies of (UN) peacekeeping operations have highlighted their many shortcomings and raise doubts on whether peacekeeping is effective (Paris 2004; Howard 2008; Autesserre 2010). Admittedly, little remains known about how peacekeeping works, and whether peacekeeping is indeed a sufficient and necessary element of conflict resolution.

It is often overlooked that the UN is only one of the many actors involved in conflict resolution (Greig and Diehl 2005; Autesserre 2014; Clayton and Dorussen 2018), and peacekeeping only one of instruments in the UN repertoire (Beardsley, Cunningham and White 2015; Benson and Tucker 2017). Ignoring the context of peacekeeping risks misattributing credit or blame. For example, the UN peacekeeping mission to Sierra Leone (UNAMSIL) is generally evaluated as successful, but the UK military intervention, operation Palliser, arguably played a crucial role in suppressing the civil war creating the necessary conditions for UN peacekeepers to operate effectively. Also in the Central African Republic, Mali and Timor-Leste, third-party military interventions (by France, NATO and Australia respectively) set the stage for UN PKOs. In Mozambique, mediation by the Vatican and the UN created conditions for ONUMOZ a highly successful UN PKO. In contrast, the Rwanda genocide was as 
much a failure of UN political involvement as peacekeeping. However, whereas comprehensive data on UN peacekeeping are increasingly available (Clayton et al 2016), information on other UN conflict resolution instruments remains limited.

A number of recent studies have begun exploring the political context of peacekeeping. Greig and Diehl (2005) argue that armed conflicts are likely to continue as long as uncertainty remains about balance of power, costs of conflict and resolve. Compared to decisive military victories, conflict outcomes supported by mediation and peacekeeping reveal less information making them less stable. Greig and Diehl (2005) and Beardsley (2008) find that mediated conflict outcomes of interstate conflict are indeed more likely to fail. Yet peacekeeping could offset the fragility of mediated outcomes. Beardsley, Cunningham and White (2015) observe that diplomatic efforts complement peacekeeping. Clayton and Dorussen (2018) also note that peacekeeping and mediation often go together. They argue that peacekeeping provides valuable information and creates favorable conditions for mediation. After the conflict officially ends, peacekeepers are often needed to support the fragile peace, while at the same time mediation is essential to ensure the effectiveness of peacekeepers. Empirically, Clayton and Dorussen (2018) find that mediation shortens armed conflict and that the pacifying effect of peacekeeping is conditional on mediation. Interestingly, they also note that with existing data it is impossible to disentangle the impact of mediation and peacekeeping on the recurrence of conflict.

To address these concerns, we have compiled data on the full range of instruments the UN employs to advance peace and stability. After briefly introducing the data, we will 
describe how they help us to identify different types of UN peacemaking instruments based on what they aim to achieve (tasks), when they are applied (trends) and to what conflicts (selection).

\section{United Nations Peacemaking Data}

The United Nations Peacemaking Initiative (UNPI) Data Project compiles data on the full spectrum of UN institutions aimed at conflict prevention and crisis management, mediation, peacekeeping and -building. The ultimate aim of the project is to provide an empirical basis to assess the relative contributions of various UN instruments that attempt to manage violent conflict. In particular, the data seeks to provide researchers the opportunity to study possible selection bias in their implementation, and any effects of how the different instruments are sequenced or applied simultaneously; in short in what ways the various instruments are complements or substitutes.

The UNPI data encompasses all UN political initiatives from 1946 until 2015, and includes information on the timing of the conflict management tools, the mandated functions, and the main actors involved. The data can be merged with existing data on UN and non-UN PKOs, third-party mediation, as well as the UCDP conflict data. The data rely on two main sources. The source of the political initiatives from the UN Security Council (SC) is the Repertoire of the Practices of the Security Council (http://www.un.org/en/sc/repertoire/structure.shtml). The Repertoire contains information on subsidiary organs and enforcement mechanisms of the SC under various headings, such as commissions and investigative bodies, sanctions committees, standing and ad hoc committees, groups and panels, international tribunals, missions of the SC and the Secretary General (SG), peace-building offices, 
peacekeeping missions, political missions and offices, representatives, mediators, coordinators and good offices, working groups, and proposed organs. The Yearly Reports (http://research.un.org/en/docs/ga/quick/regular/1) of the General Assembly (GA) are the source of information on its subsidiary organs, only including those with a peace and stability mandate, and encompassing boards, commissions, committees, assemblies and councils, working groups, positions or bodies recommended by the GA and created by the SG (if they are unrelated to the SC). The GA data also include subsidiaries of abovementioned organs; such as the Peacebuilding Commission and the election observation operations from the Human Rights Commission. UNPI includes 478 unique UN missions encompassing 3,351 mission years.

\section{Tasks of Political Missions}

Political missions are mandated to implement a wide variety of tasks. UNPI identifies 36 different 'functions', and regularly missions have multiple tasks. The most common ones are guidance - reporting and offering suggestions to the $\mathrm{UN}$ and the SC (mandated for 212 missions or 36\% of all missions), implementation (209 missions or $35 \%)$, conflict management in the form of mediation, good offices and negotiations (202 missions, or 34\%), and political development by means of supporting and restoring administrative functions (197 missions or 33\%), and observation mandated for 179 missions (30\%). The data identify 115 decolonization committees (20\%); generally linked to the Special Committee on Decolonization established by the UN General Assembly. Notably, the mandates of political missions regularly vary over time, which is captured in the yearly version of UNPI. 
The official ‘classification' of different types of political missions in the Repertoire and Yearly Reports varies over time making it of limited use. Instead, UNPI classifies political missions around four thematic clusters: diplomatic, technocratic, political development and peacekeeping. The clusters correspond roughly to division of political missions used in UN documentation (United Nations 2013), but applied to the full range of missions. Approximately $11 \%$ of all missions are diplomatic, encompassing special envoys, advisers, representatives and mediators; for example, part of the UN Department of Political Affairs, the Special Adviser to the Secretary General on Cyprus, Mr. Espen Barth Eide represents the UN Security Council on all matters related to the peace process. Technocratic missions include sanctions monitoring teams, panels, ad hoc committees, groups of experts and investigations $(\approx 42 \%)$. As an example, UN Security Council Resolution 1564 requested the Secretary General to set up the International Commission of Inquiry on Darfur to investigate reports of violations of international humanitarian and human rights law, and to report back to the Security Council. Missions in the political development clusters include commissions, UN field offices, peace-building missions, and tribunals $(\approx 23 \%)$. The UN Assistance Mission for Iraq (UNAMI) is an example of a political mission established by UN Security Council Resolution 1500 at the request of the Iraqi government. UNAMI supports political and electoral developments and coordinates humanitarian support. UNAMI is administered by the UN Department of Political Affairs, but supported by the UN Department of Peacekeeping Operations.

The fourth cluster, peacekeeping missions (for example MONUSCO in the Democratic Republic of the Congo) and military observers (such as UNMOGIP at the border between India and Pakistan), encompass about $24 \%$ of all missions. 


\section{Trends}

The number of political and peacekeeping missions has been increasing over time. Figure 1 shows that the trend of different types of political missions.

The number of political missions began to increase from the early 1960 s.

Technocratic missions (including sanctions and decolonization) committees witnessed a strong growth in the 1960s following the establishment of the Special Committee on Decolonization in 1961. Political missions, however, were already in this early period an important conflict management tool and outnumbered peacekeeping missions.

The pattern is even more apparent in the post-Cold War period where the number of political missions has grown dramatically, while the number of peacekeeping missions has remained relative stable after an initial jump from about 10 to 20 missions. All types of missions increased in the post-Cold War period, and the number of diplomatic, technocratic and political missions exceeded the number of peacekeeping missions from 2005. These developments show how the UN has been giving increasing importance to its political initiatives. 


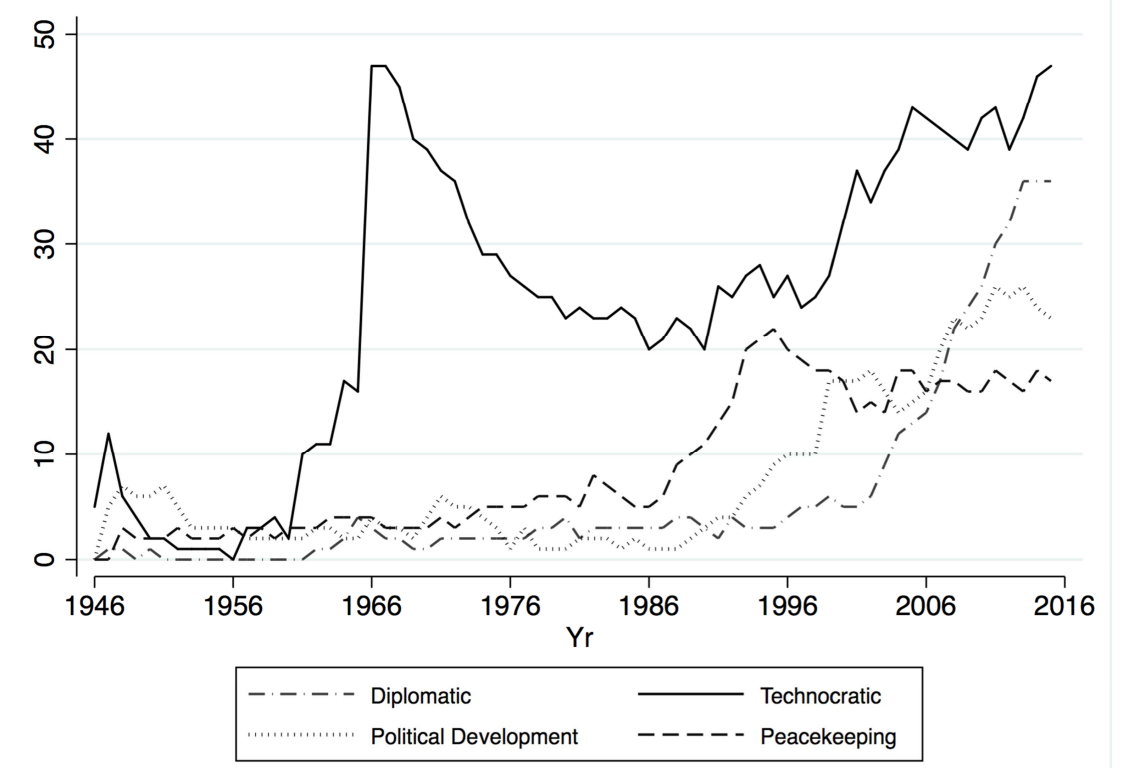

Figure 1: Number of Diplomatic, Technocratic, Political Development, and Peacekeeping Missions per year

\section{Political Missions and Conflict Resolution}

An interesting feature of the $U N P I$ data is that it links political missions with specific armed conflicts. Political missions carry out good offices and conflict prevention, but inevitably these efforts fail to avert conflict in a number of cases. The peacemaking and -building activities of political missions regularly extend post-conflict. Table 1 shows the frequency with which political and peacekeeping missions are linked to conflict, indicating if a mission was present in the period before, during, and after conflict. Technocratic and peacekeeping missions are the most frequent prior to conflict, though a relatively high percentage of diplomatic missions also occur in this period. Technocratic and peacekeeping missions are the most likely to engage in peacemaking. A high proportion of diplomatic and political development missions occur after conflict, and as expected, there is also a high frequency of peacekeeping missions in this period. 
Table 1: Political and Peacekeeping Missions and Conflict

\begin{tabular}{lrrrr}
\hline UN Missions & \multicolumn{3}{c}{ Conflict } \\
& \multicolumn{1}{c}{ Before } & \multicolumn{1}{c}{ During } & \multicolumn{1}{c}{ After } & \\
\cline { 2 - 4 } Diplomatic & $56(19 \%)$ & $119(41 \%)$ & $118(40 \%)$ & $293(100 \%)$ \\
Technocratic & $170(26 \%)$ & $393(60 \%)$ & $91(14 \%)$ & $654(100 \%)$ \\
Pol. Development & $51(10 \%)$ & $273(53 \%)$ & $194(37 \%)$ & $518(100 \%)$ \\
Peacekeeping & $97(15 \%)$ & $358(57 \%)$ & $178(28 \%)$ & $633(100 \%)$ \\
All & $374(12 \%)$ & $1,143(39 \%)$ & $581(49 \%)$ & $2,098(100 \%)$
\end{tabular}

Note: Mission-year observations linked to conflict out of a total of 3,351 mission-year observations. Conflict-years identified via UCDP data.

Table 2 provides a cross tabulation of the various clusters of political missions and different conflict outcomes, defined according to the UCDP Conflict Termination Dataset (Kreutz 2010). Peacekeeping missions are regularly deployed as part of a peace agreement and, as shown in Table 2, are indeed somewhat more often associated with this outcome. Peacekeeping missions are also somewhat less associated with military victories, or when one side has comprehensively defeated or eliminated the opposition, who may have recognized defeat through capitulation or public announcement. In contrast, diplomatic missions are relatively more often associated with military victories, but less with stalemates. Stalemates are defined as 'low activity' outcomes with the incompatibility unresolved and conflict activities continuing but with less than 25 battle-related deaths in any given year. A similar pattern applies to political development missions. Finally technocratic missions are concentrated in stalemates, while relatively less deployed to conflict that end (or have ended) in either a peace agreement or a military victory for one side. Table 2 gives some preliminary indication of the effectiveness of the various conflict management tools at the disposal of the UN, but also shows that different clusters of missions are 
not randomly deployed. It follows that a full analysis of the relative effectiveness of the various clusters of missions needs to control for selection bias.

\begin{tabular}{lrrrr}
\hline \multicolumn{4}{l}{ Table 2: Political and Peacekeeping Missions and Conflict Outcome } & \\
\hline UN Missions & Peace & Military & Stalemate & \\
Agreement & Victory & & \\
Diplomatic & $5(36 \%)$ & $5(36 \%)$ & $4(29 \%)$ & $14(100 \%)$ \\
Technocratic & $9(30 \%)$ & $6(20 \%)$ & $15(50 \%)$ & $30(100 \%)$ \\
Political & $10(38 \%)$ & $8(31 \%)$ & $8(31 \%)$ & $26(100 \%)$ \\
Development & & & & \\
Peacekeeping & $15(39 \%)$ & $9(24 \%)$ & $14(37 \%)$ & $38(100 \%)$ \\
All & $39(36 \%)$ & $28(26 \%)$ & $41(38 \%)$ & 108 \\
\hline
\end{tabular}

Note: Missions linked to conflict out of a total of 471 missions. Conflict episodes identified via UCDP data. *Otcome coded as stalemate if number of battle deaths in Comment [HD1]: CORRECT IN any year dropped below 25 .

\section{Conclusions}

In contrast to increasing academic interest in UN peacekeeping missions, relatively little attention has been paid to its political initiatives. Yet the UN responds to conflicts using a range of tools, which increasingly involves political missions. The UNPI data highlights the varied collection of instruments and functions undertaken by existing bodies. It promises to address the current lack of understanding of why and where missions, other than peacekeeping, are deployed. Eventually, the data should help us to determine the effect of these different forms of missions on conflict and conflict resolution.

In evaluating the relative effectiveness of different conflict management tools, it is arguably important to consider the context in which they are deployed. Possible 
selection bias is now commonly recognized as an issue for studying the effectiveness of peacekeeping. There is however good preliminary evidence to suggest that it may also be an issue when studying political missions. Possibly, even more important is that different types of missions are often deployed simultaneously or sequentially. This has not only important implications for research design, but also clearly for policy research. As recently noted by UN Secretary Guterres:

I call on Member States to sustain your political engagement and push for political solutions and inclusive peace processes, including through bilateral diplomacy and sanctions if necessary. A peacekeeping operation is not an army, or a counter-terrorist force, or a humanitarian agency. It is a tool to create the space for a nationally owned political solution. ${ }^{1}$

Yet the need for coordination between different political and peacekeeping missions has received only limited academic attention so far; see Heldt (2013) for an exception. The Peacemaking Data will thus be important for a number of research questions, such as, why particular countries and conflicts witness certain types of political missions; when do different UN missions complement, substitute, or possibly even undermine other forms of conflict management, and what are the effects of political missions beyond conflict management, e.g., on one-side violence, the implementation of peace agreements, democratization, economic development, refugees and internally displaced persons?

\footnotetext{
${ }^{1}$ UN Secretary General Guterres remarks to Security Council High-Level Debate on Collective Action to Improve UN Peacekeeping Operations, 28 March 2018
} 


\section{References}

Autesserre, Séverine (2010). The Trouble with the Congo; Local Violence and the Failure of International Peacebuilding. Cambridge: Cambridge University Press.

Autesserre, Séverine (2014). Peaceland. Conflict Resolution and Everyday Politics of International Interventions. New York: Cambridge University Press.

Beardsley, Kyle (2008). “Agreement without peace? International mediation and time inconsistency problems," American Journal of Political Science 52(4): 723740.

Beardsley, Kyle, David E. Cunningham, and Peter E. White (2015). “Diplomacy, Peacekeeping and the Severity of Civil War.” Paper presented at Annual Meeting of the American Political Science Association in San Francisco, September 3-6, 2015.

Benson, Michell, and Colin Tucker (2017). Naming Names in UNSC Conflict Resolutions: Implications for Peacekeeping. Paper presented at the Folke Bernadotte Academy workshop in Addis Ababa, October 8, 2017.

Clayton, Govinda, J. (ed.), Kathman, K. Beardsley, T.-I. Gizelis, L. Olsson, V. Bove, A. Ruggeri, R. Zwetsloot, J. van der Lijn, T. Smit, L. Hultman, H. Dorussen, A. Ruggeri, P.F. Diehl, L. Bosco, and C. Goodness (2016). “The known knowns and known unknowns of peacekeeping data," International Peacekeeping, DOI: $10.1080 / 13533312.2016 .1226768$.

Clayton, Govinda, and Han Dorussen (2018). The Effectiveness of Mediation and Peacekeeping for Global Conflict Management. Paper presented at the Annual Convention of the International Studies Association, San Francisco, April 4 - 7, 2018. 
Doyle, Michael W, and Nicholas Sambanis (2006). Making War and Building Peace.

United Nations Peace Operations. Princeton: Princeton University Press.

Fortna, Virginia P. (2008). Does Peacekeeping Work? Shaping Belligerents' Choices after Civil War. Princeton: Princeton University Press.

Greig, Michael J., and Paul Diehl (2005). “The Peacekeeping-Peacemaking

Dilemma,” International Studies Quarterly 49(4): 621-645.

Heldt, Birger (2013). "The Lack of Coordination in Diplomatic Peacekeeping," Penn State Journal of Law \& International Affairs 2(1): 9 - 16.

Howard, Lise M. (2008). UN Peacekeeping in Civil Wars. Cambridge: Cambridge University Press.

Hultman, Lisa, Jacob Kathman, and Megan Shannon (2013). “United Nations Peacekeeping and Civilian Protection in Civil War," American Journal of Political Science 57(4): 875-891.

Hultman, Lisa, Jacob Kathman, and Megan Shannon (2014). “Beyond Keeping Peace: United Nations Effectiveness in the Midst of Fighting," American Political Science Review 108(4): 737-753.

Kreutz, Joakim, 2010. "How and When Armed Conflicts End: Introducing the UCDP Conflict Termination Dataset," Journal of Peace Research 47(2): 243-250.

Paris, Roland (2004). At War's End: Building Peace after Civil Conflict. Cambridge: Cambridge University Press.

Ruggeri, Andrea, Han Dorussen, and Ismene Gizelis (2017). "Winning the Peace Locally: UN Peacekeeping and Local Conflict," International Organization 71 (1): $163-185$.

United Nations (2013). United Nations Political Missions: Report of the Secretary General. 


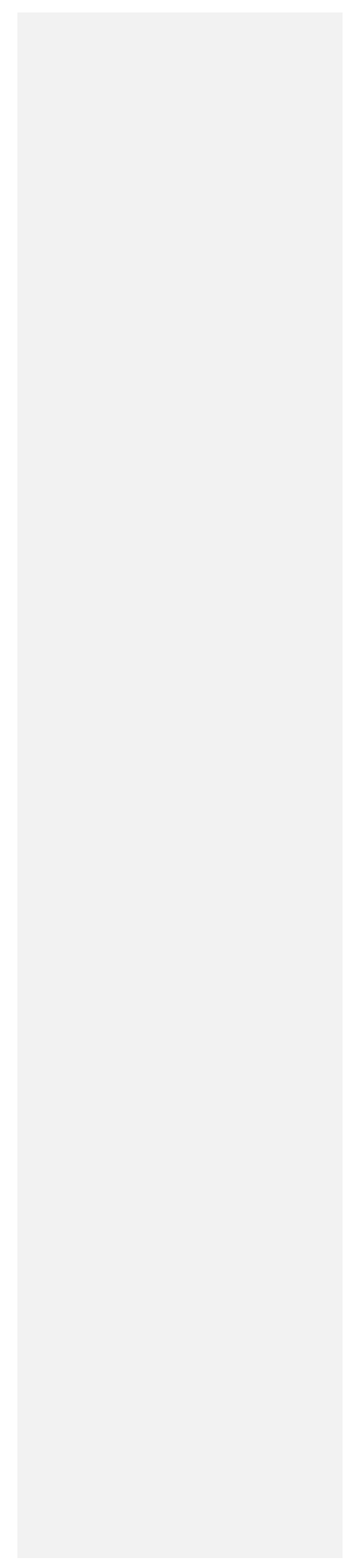

